\title{
Attitudes of the Portuguese Elites towards the European Union
}

\section{Diogo Moreira, João Pedro Ruivo, António Costa Pinto \& Pedro Tavares de Almeida}

The purpose of this article is to present and discuss the data for Portugal of the IntUne survey on elite attitudes towards European integration. Despite some differences between the Portuguese and the European results of the survey, we find that the concept of 'compound citizenship' (M. Cotta, 'A “compound” model of citizenship? European citizenship in the eyes of national elites', Lisbon IntUne General Assembly, 27-30 November 2008) may be applied to the perceptions of Portuguese elites regarding the European Union, and the postulated combination of an indirect European citizenship with a direct one is also verifiable in Portugal. We hypothesise that this European 'compound citizenship' is not conflictive with national citizenship, possessing instead elements for strengthening the linkage between them.

Keywords: Portuguese Elites; EU; Citizenship; European Identity; Portugal; IntUne Survey

This article describes and analyses the data for Portugal collected by the IntUne survey on elite attitudes towards the European Union (EU). Following a brief historical overview of Portugal's path to European integration, it focuses on three major dimensions of European citizenship —identity, representation, and scope of governance-and explores the views that Portuguese political and economic elites have about them. Theoretically, its approach is based on the 'compound' model of citizenship (Cotta 2008) which views European citizenship as the result of a conflation of direct and indirect elements, and it aims at shedding some light on the links between citizenship and polity at the national and European levels. With regard to political elites, our analysis explores how ideological orientations influence attitudes towards different aspects of European citizenship.

\section{Historical Overview}

When Portugal became a member of the European Economic Community (EEC), in 1986, expectations were high and largely optimistic. The governing elites successfully 
sought to legitimate the new democratic order using Europe and EEC membership. In doing so, they adopted a very positive view of European integration that impacted favorably on public opinion.

A founding member of the North Atlantic Treaty Organisation (NATO), Portugal did not experience the same level of international isolation as its Spanish neighbour following the Second World War (Pinto \& Teixeira 2003). Receipt of the Marshall Plan, membership of European Free Trade Association (EFTA) and-following the application of the United Kingdom - a trade agreement with the EEC in 1972 are examples of the pragmatic approach the authoritarian regime took towards European integration, in spite of the isolationist resistance to decolonisation in the 1960s (Alípio 2006; Leitão 2007). Nevertheless, in the context of the polarised transition to democracy in 1974-76, when the crucial political divisions corresponded to a conflict 'between democrats and revolutionaries [rather] than between democrats and "involutionaries" (Álvarez-Miranda 1996, p. 202), the European option was an important factor in the break from a dictatorial and colonialist past, and also assumed an anti-communist and anti-revolutionary orientation (Pinto \& Teixeira 2003).

As in other South European transitions to democracy-particularly in Spain-'the idea that accession to the European Community would help guarantee liberal democracy was more overtly voiced' (Álvarez-Miranda 1996) and was central to the strategy of the political elites during this period. The swift Europeanisation of the newly founded parties was also stimulated by their merging in the transnational networks of the European political families. The theme of EEC membership soon emerged in the programmes of the right and centre-right parties, the Social Democratic Centre (CDS, Centro Democrático Social) proclaiming itself fully proEuropean, and the Social Democratic Party (PSD, Partido Social Democrata) adopting a more cautious approach (Barroso 1983). The CDS, which was affiliated to the European Christian Democratic family, adopted a strongly pro-European strategy right up to accession. The PSD, which was formed by the reformers and 'liberals' of the dictatorship's final years, first inserted itself into the European 'liberal' family, although it defected to the European People's Party in 1996. In 1976, the main slogan of the electoral campaign of the Socialist Party (PS, Partido Socialista Português) was 'Europe with us', and the proposal of EEC accession was incorporated in the party's programme.

The arguments in favour of the EEC were actively promoted as the means to implement the necessary political and constitutional reforms for democratic consolidation. Only the Communist Party (PCP, Partido Comunista Português) remained consistently opposed to EEC membership, and rejected the prospect of accession. This opposition was an important element in its political campaigns between 1977 and 1986. After 1986, the PCP stopped calling for Portugal to withdraw from the EEC, and adopted a more moderate position. Following the Maastricht Treaty, and with the challenge of a new competitor, the emergent Left Bloc (BE, Bloco de Esquerda), the Communists again reinforced their critical stance, focusing on the neo-liberal orientation taken by the EU. In the early 1990s, the CDS renamed 
themselves the Popular Party (PP). Under a new leadership, they also became more Eurosceptic. Nevertheless, since the PS and the PSD have been strongly pro-European and, as there is a trend of vote concentration in these two major parties, which have polled together around 70 per cent, there is not a significant division on EU issues.

Civil society and the interest groups representing those who would be most affected by EU membership had practically no role to play during any stage of the accession negotiations. European integration was a decision made by the political elite alone, rather than 'a response to popular demand' (Bermeo 1988, p. 14). The governing elites dominated the negotiating process, with only limited involvement of business associations or agricultural organised interests. Both the Confederation of Portuguese Industry (CIP, Confederação da Industria Portuguesa) and the Portuguese Industrial Association (AIP, Associação Industrial Portuguesa) supported accession, although to different extents. The CIP wavered between domestic liberalisation and protectionism towards the EEC, at the beginning demanding more pre-entry economic aid, and later on showing opposition to the final agreements. The AIP adopted a more pragmatic 'join and see' position. Nevertheless, despite the CIP's occasional attacks, the hypothesis that the attitudes of these two organisations reflected an attempt to make the government adopt an aggressive negotiating stance, rather than any principled opposition appears plausible, especially since these attitudes did not enjoy much support among their affiliates. Several interviews with leading figures of the employers' organisations reveal that their attitudes towards accession were driven by political considerations, the EEC being presented as the 'guarantor for greater political security that will encourage investment in and modernisation of the productive structures in the country' (Lucena \& Gaspar 1991, p. 899).

Portugal's route to EEC membership was therefore promoted by the political elite, with a great degree of political consensus, and without any attempt to assess public opinion through referenda. It was not until after accession had been secured that popular opinion began to call for more public participation in the reforms that were taking place within the EU. The perception of EEC membership as a positive goal was initially restricted to the political elite. In 1978, shortly after the formal membership application had been submitted, most Portuguese had no opinion on Europe, and over 60 per cent of the population stated that they did not know whether EEC membership was essential for the future of Portugal's economy (Bacalhau 1994). It was not until the early 1980s that the Portuguese became better informed and thus able to express a clearer opinion on the subject. The Eurobarometer survey has regularly recorded Portuguese public opinion since 1980, and its reports have revealed a clear upward trend in support of EEC membership, a large increase occurring in 1986, the year Portugal finally joined. The proportion of the population believing EEC membership to be 'a good thing' rose from 24.4 per cent in 1980-82 to 64.5 per cent in 1986-90 and finally to above 70 per cent during the early 1990s (Bacalhau 1994, p. 269). In 1993, 65 per cent believed that Portuguese economic development had been boosted greatly as a result of EEC membership. As appears to be the case in other South European countries, there seems to be a strong suggestion that the urban middle 
classes generally tend towards pro-Europeanism and have only a weak sense of 'national pride', while the less educated and the rural lower classes generally have weak pro-European sentiments and a strong sense of 'national pride' (Cruz 1993, p. 157)

The first ten years of Portugal's membership in the EEC/EU was a 'golden era', with a large degree of pro-European consensus within the party system. There was a wave of economic growth and rising incomes, as well as real social change (Barreto 2003). Internationally, Portugal used its stronger position as a member of the EU to resolve the tensions prevailing with its former colonies in Africa. The optimism of the 1990s was also marked by Portugal's meeting the convergence criteria for adoption of the euro, which occurred in 1999-2000. This contrasted with the situation at the beginning of the following decade. With the EU's movement towards enlargement and institutional reform, as well as the eventual reduction of EU financial support, Portuguese public opinion became less optimistic (Pinto \& Lobo 2004).

On the whole, Portuguese attitudes towards the EU have been overwhelmingly positive. However, it is important to note that the Portuguese consensus is based on a narrow, instrumental view of the benefits of membership for Portugal rather than on wider perceptions of the EU as 'a good thing'. In terms of attitudes towards the EU as a political system, the evidence is somewhat paradoxical: whereas the Portuguese show little participation in the European Parliament (EP) elections and are dissatisfied with the way democracy works in the EU, they have increasingly defended the Europeanisation of key public policies such as foreign affairs and currency matters (Pinto \& Lobo 2004, p. 181). This concurs with the view that Portuguese attitudes are positive, but are formed on an instrumental basis.

\section{Elite Attitudes towards the EU: The 2007 IntUne Survey}

Elite surveys are rare in Portugal, and the 2007 IntUne survey is the most comprehensive one on European issues that has been conducted thus far. The survey was carried out between February and March for the political elite respondents and between March and May for the economic elite respondents. Following the sampling criteria and procedures set up by the IntUne project, the group of interviewees included $80 \mathrm{MPs}$ and 40 businesspeople and top officeholders of major interest organisations. ${ }^{1}$

In this article, we compare the general attitudes of the two types of elites, applying the left-right division to further differentiate among the group of politicians. Ideologically, we categorised the MPs as follows: the left includes all respondents who are members of the PCP/PEV (the alliance between the Communist Party and the Green Party ${ }^{2}$ ) and of the BE. The centre-left is composed of all respondents who belong to the PS, the single party in government with an absolute majority when the IntUne survey took place. The centre-right aggregates the respondents of the PSD, historically the alternative party of government. The right is represented by all respondents who are members of the CDS/PP. With the significant exception of the BE, which emerged in the late 1990s, the other four major parties have been the central actors in the parliamentary arena since 
the elections of 1975, a defining moment in the democratic transition. A trend of vote concentration in the two large centre parties, the PS and the PSD, developed from 1987 onwards, ${ }^{3}$ and since then the two of them together have controlled more than fourfifths of the parliamentary seats (Almeida \& Freire 2005, pp. 457-462).

From a theoretical view, we apply the 'compound' model of citizenship (Cotta 2008) to the analysis of the elusive concept that is European citizenship. The term 'compound citizenship' refers to the idea that European citizenship is actually an amalgamation of two separate but intertwined dimensions: an indirect citizenship that is derived from the national citizenship of a member state of the EU, and a direct one that is originated and established by the existence of a system of European institutions. European citizenship is further characterised by an horizontal dimension that defines the membership linkage with the European polity, and by a vertical dimension that concerns the relationship between the European citizens and the authorities of the EU (Cotta \& Isernia 2009).

Following the guidelines of the IntUne project, we will present and discuss here descriptive data on three major dimensions of Europeanness - identity, representation, and scope of governance. The topics covered range from the degree of attachment to different territorial communities and the basic elements considered to be constitutive of the European and the national identity, to the levels of trust in both European and Portuguese institutions and the evaluation of EU common policy areas and levels of policymaking.

\section{Allegiance to Different Territorial Entities}

In order to explore the horizontal dimension of European citizenship, we have analysed the feelings of attachment of elites to different territorial levels, their evaluation of the benefits produced by membership in the EU, and their conceptions of what defines the national as well as the supranational identity.

Regarding the different levels of territorial attachment of the respondents (see Table 1), we find that all Portuguese elite groups consider themselves strongly attached to Portugal as a country, first and foremost, and also strongly attached to their town and village. This perception prevails in all ideological groups. When we look at the regional attachment, we find that the consensus is broken. The respondents of the political elite are much more attached to their regions (61 per cent are 'very attached') than those of the economic elite (only 32 per cent are 'very attached'). Analysing the political groups, the centre-right and the left show, respectively, the highest (65 per cent) and the lowest (38 per cent) proportion of respondents attached to the regions. Finally, a very large majority of the political and economic Portuguese elite feel attached to the EU. However, if one considers only the strongest expression of attachment, the difference between the European and the national levels is significant. This result seems to confirm the idea that a feeling of supranational belonging can coexist with the national one, and also that it is felt as being indirect and therefore weaker in intensity. 
It can also be noted that the supranational allegiance is stronger among the MPs (45 per cent) than the businessmen (38 per cent). From an ideological standpoint, only the left ( $\mathrm{BE}$ and $\mathrm{PCP} / \mathrm{PEV}$ ) appears to have a relevant number of respondents (24 per cent) who do not consider themselves attached to the EU, which could explain some of the less positive views about the EU that this group will show along this study.

In most mass opinion surveys, when asked about the benefits of the European integration process, the majority of the Portuguese believe that it is a good thing and that Portugal has benefited from it. Thus it should not be a surprise that Portuguese elites overwhelmingly believe that Portugal has benefited from the European integration process. The only exception is the left: two-thirds of respondents from the $\mathrm{BE}$ and the PCP/PEV claim that Portugal has not benefited from being a member state of the EU.

\section{Identity}

While examining how elites define territorial identities at the national level, Table 2 shows that the attribute of being Christian is considered 'not important' by a large majority of both the political elite (74 per cent) and the economic elite (66 per cent). When we turn to a detailed analysis of the political elite, based on party affiliations and ideological self-positioning, we find a significant distinction: most respondents on the left consider the religious attribute irrelevant, while half of the respondents on the right believe it is 'somewhat/very important'.

The sharing of Portuguese cultural values is consensually considered 'somewhat/very important' by both the political ( 94 per cent) and the economic ( 95 per cent) elites. Surprisingly, the less favourable attitude in this overwhelming consensus comes from those on the far right of the political spectrum: only 75 per cent considered it 'somewhat/very important'. All the other groups show percentages well beyond the 90 per cent level.

Being born in the national territory is considered a 'very/somewhat important' attribute by 66 per cent of the MPs and 70 per cent of the businesspeople. Both the left and the right seem to differentiate themselves from the consensus on this matter. Only 38 per cent of those who are members of the BE or of the PCP/PEV, as well as 25 per cent of their ideological counterparts on the right, feel that being born in Portugal is considered an important feature of national identity. The nationality of one's parents is also considered important by an overwhelming majority of the political (78 per cent) and the economic (76 per cent) elites. In terms of political groups, only the left diverges from this opinion.

The respect for national laws and traditions is seen as 'somewhat/very important' across the elites (98 per cent of the politicians and an equal percentage of businesspeople). The slightly lower importance ( 95 per cent) accorded to this element by those who place themselves at the centre-left of the ideological spectrum (in comparison with those on the left, centre-right and right) should be noted. 


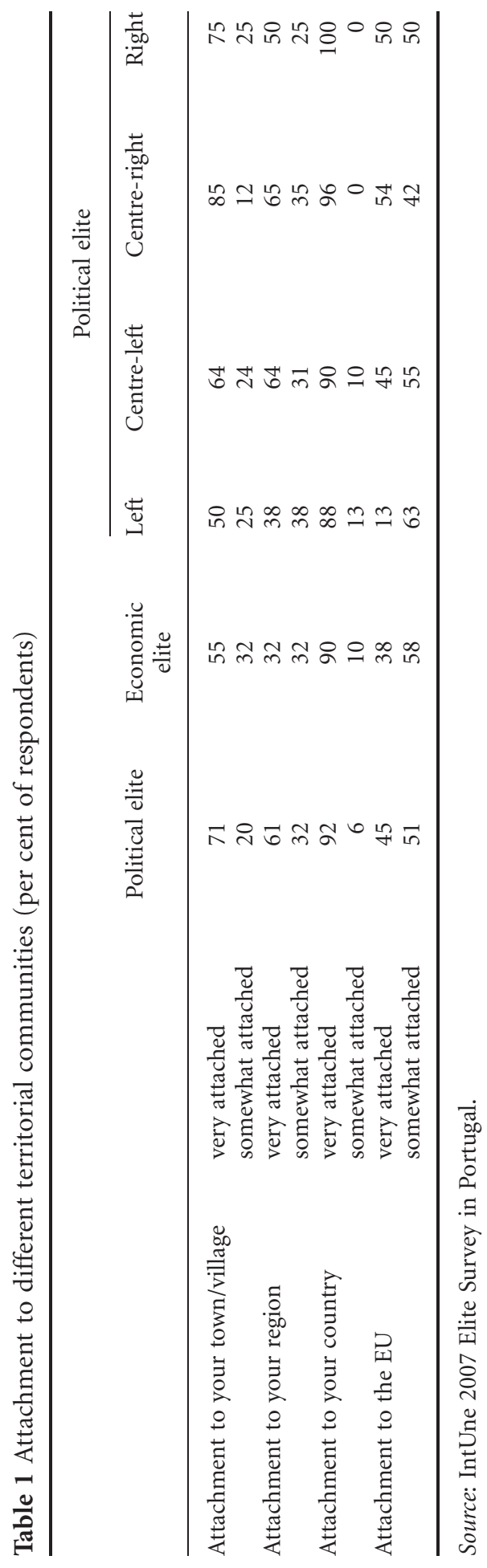




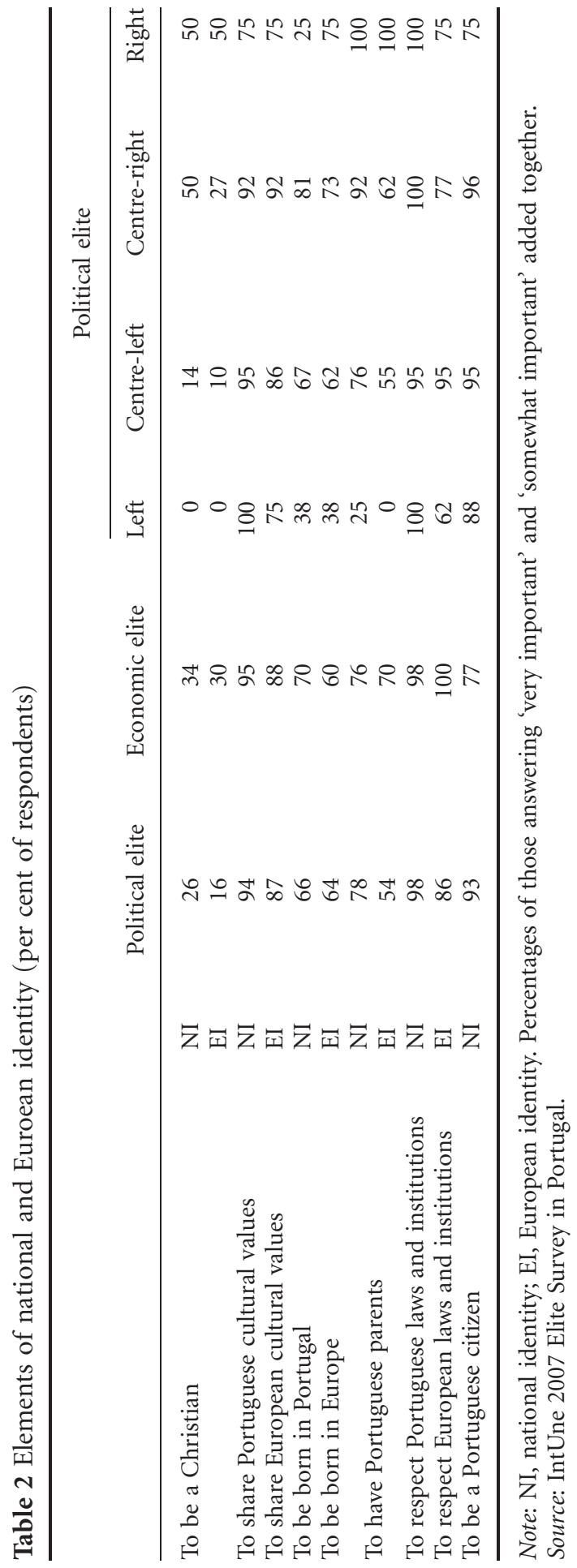


We now turn to the elements of identity that are associated with the supranational level of the European integration process (Table 2), in an attempt to determine the meaning that the Portuguese elites attribute to the blurry concept of European identity.

Starting with the religious dimension, we find great similarities with the attributes of national identity. Once again, the fact that someone is Christian has little relevance for both the political (16 per cent) and economic (30 per cent) elites. As regards MPs, this appears to be one of the clearest issues in terms of ideological positioning. The left unanimously agrees that religion is not a relevant attribute in terms of European identity, while 50 per cent of respondents on the right express the opposite opinion.

A more fundamental consensus about European identity appears when we focus on cultural values. The same proportions ( $87-88$ per cent) of both elite groups claim that sharing European cultural values is an important attribute of European identity.

The fact that someone was born in a European country is seen generally by the political and economic elites as an important attribute of his/her European identity. Once again, this is one of the few items where we find a clear ideological division among the politicians. Birthplace is considered a relevant characteristic by only a minority on the left (38 per cent) while the remaining respondents hold the opposite position.

Having European parents is another attribute of European identity that is considered important to the majority of the political (54 per cent) and the economic (70 per cent) elites. However, we must emphasise the high degree to which the economic elite tends to support this claim vis-à-vis their political counterpart. In terms of political groups, the respondents of the BE and the PCP/PEV clearly reject this attribute as an important one. The centre-left tends to follow the general opinion in this matter. Finally, respect for European institutions and laws is valued as an important attribute of European identity by all elite groups.

Ever since Linton (1936), the terms 'ascribed' and 'achieved' have contrasted inherited attributes - i.e. those not depending on the subject's will—with those that depend upon the subject's actions. Parsons (1951) has demonstrated the importance of these two concepts as characterisations of social roles, and they have remained important sociological analytical tools. It has been pointed out that ascribed and achieved components exist in both national and European identities (Sanders 2008). Religion, birthplace and parenting are associated with the ascribed dimension of identity, whereas culture, respect of law, feelings and language are achieved components.

Using factor analysis for the Portuguese elite sample, we find an ascribed component of European identity, with birthplace and parents' origin as a part of the same factor (Table 3). Likewise, there appears to be an achieved dimension, 'the respect for law and institutions' and the 'feeling of being European' being associated in the same factor. Moreover, we find a high and positive interaction with the religious and cultural attributes. This seems to indicate that the cultural dimension of European identity in Portugal is greatly associated with Christianity. This concurs with the idea 
Table 3 Components of European identity: factor analysis

\begin{tabular}{lccc} 
& \multicolumn{3}{c}{ Component } \\
\cline { 2 - 4 } Rotated component matrix & Ascribed & Achieved & Cultural/religious \\
\hline To be born in Europe & 0.857 & -0.139 & 0.125 \\
To have European parents & 0.871 & 0.153 & 0.046 \\
To respect EU laws and institutions & 0.006 & 0.847 & -0.119 \\
To feel European & 0.007 & 0.813 & 0.201 \\
To be a Christian & 0.128 & -0.032 & 0.707 \\
To share European cultural traditions & 0.017 & 0.094 & 0.774 \\
Rotation sums of squared loadings & 25.169 & 23.846 & 19.523 \\
\hline
\end{tabular}

Note: Extraction method: principal component analysis. Rotation method: Varimax with Kaiser normalisation. Rotation converged in four iterations; variables that loaded on more than one factor were removed.

Source: IntUne 2007 Elite Survey in Portugal.

of Europe as a 'torn country, deeply divided over its cultural identity, unable to answer the question of whether European unity ... should be defined by the common heritage of Christianity and Western civilisation or by its modern secular values' (Casanova 2006, p. 74).

With regard to the components of national identity, birthplace and parents' origin are part of the ascribed component see Table 4. In the Portuguese elites, the feeling of being Portuguese, mastering the Portuguese language and sharing Portuguese cultural traditions-elements that constitute the achieved component on the European scaleare also strongly and positively loaded in the same factor. This indicates that, likewise, there exists an achieved component of national identity.

Table 4 Components of national identity: factor analysis

\begin{tabular}{lrrr} 
& \multicolumn{3}{c}{ Component } \\
\cline { 2 - 4 } Rotated component matrix & Achieved & Ascribed & Citizenship \\
\hline To share cultural traditions & 0.628 & 0.179 & 0.002 \\
To feel Portuguese & 0.716 & -0.121 & 0.227 \\
To master the Portuguese language & 0.846 & -0.095 & -0.089 \\
To be born in Portugal & -0.015 & 0.820 & 0.070 \\
To have Portuguese parents & -0.041 & 0.806 & -0.023 \\
To be a Christian & 0.195 & 0.378 & -0.458 \\
To be a Portuguese citizen & 0.050 & 0.088 & 0.872 \\
To respect Portuguese laws and institutions & -0.059 & -0.011 & -0.324 \\
Rotation sums of squared loadings & 20.838 & 19.113 & 14.260 \\
\hline
\end{tabular}

Note: Extraction method: principal component analysis. Rotation method: Varimax with Kaiser normalisation. Rotation converged in four iterations.

Source: IntUne 2007 Elite Survey in Portugal. 


\section{Representation}

Having explored the horizontal dimension of citizenship, we may now switch our attention to the vertical one. With regard to the dimension of representation, we will first analyse how trust in European institutions compares with trust in the national ones, then how elites evaluate the representation of national interests in the European sphere, and finally we will examine their views about the main institutions of the EU.

Trust in a country's political institutions (especially government and parliament) is one of the questions most frequently addressed to European audiences, usually attempting to compare it with the trust they have in European institutions. Generally speaking, in Portugal, the national government and parliament have low levels of public trust; on the contrary, the levels of trust in European institutions are considerably higher (European Commission 2008a, p. 13). When we look at the results of the IntUne elite survey, a comparison between trust in the Portuguese and the European institutions is only possible for the economic elite (Table 5). Surprisingly, and in contrast to the mass surveys (e.g. Eurobarometer), the Portuguese economic elite tends to have more trust in the Portuguese political institutions than in the European ones. The institution they trust the most is the Portuguese national government, while the local and regional governments are the institutions they trust the least.

When we compare trust in European institutions among MPs and businesspeople, the former tend to have more trust in the EP and the European Council of Ministers than do their economic counterparts. The reverse is true when the topic becomes the European Commission, which is more trusted by businesspeople than by Portuguese MPs. This could be a by-product of the Commission being seen as a less political institution than the others.

When we turn to the ideological composition of the political elite, we find that the left shows far less confidence in all the European institutions than the other groups. The question of whether Portuguese interests are taken enough into account in the EU is also routinely asked in mass surveys (European Commission 2008a, p. 36), and often the results show a fairly even split in opinion. As for the perspective of the elites, the majority of the businesspeople (60 per cent) believe that Portuguese interests are not influential in European decision-making, while a thin majority (53 per cent) of the MPs have the opposite opinion.

If we consider the party affiliation and ideological profile of the respondents, we find that the members of the BE and PCP/PEV unanimously hold the opinion that Portuguese interests have a limited influence in Brussels, and the same opinion is found amongst the most right-wing respondents. An opposite view is shared by the majority of the respondents of PS (63 per cent) and PSD (62 per cent), the two mainstream parties that have been the pillars of government in Portuguese democracy.

Another topic that was addressed by the IntUne survey on the Portuguese elites concerns their views about the powers of the three primary actors of the EU: the EP, the member states and the Commission. As we can see, the Portuguese political elite 


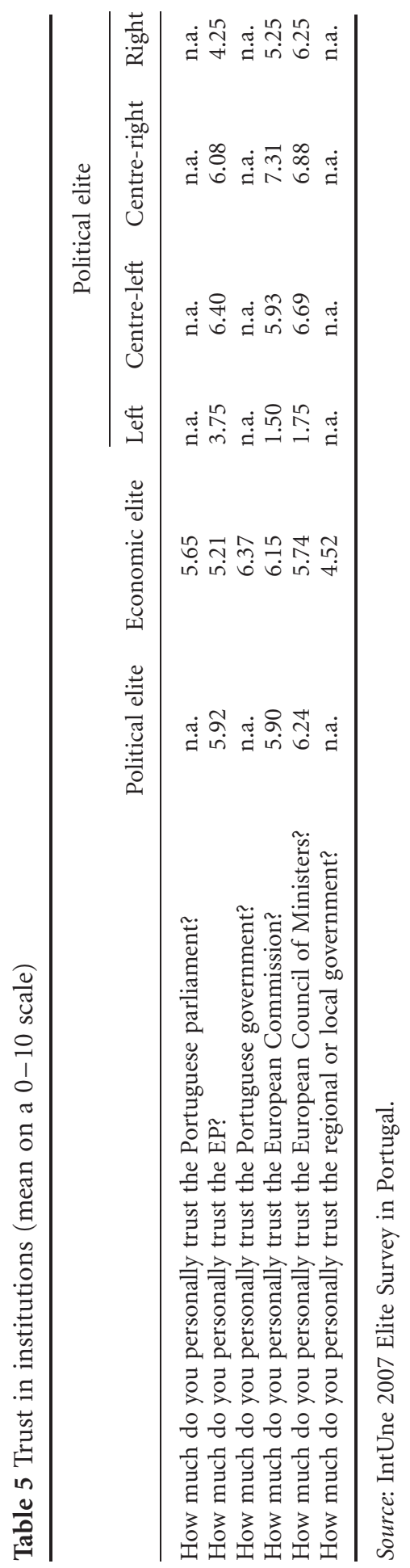


tends to fundamentally support the role of the EP and of the member states in the European political process (Table 6). The Commission is seen less positively by the MPs, only 43 per cent believing it should become the true government of the EU. This contrasts with the economic elite: 58 per cent of respondents are in favour of a much stronger role for the Commission in the European process, although they likewise want the member states to remain the central actors (76 per cent) and advocate the strengthening of the EP's powers (64 per cent).

Looking at the ideological composition of the Portuguese political elite, we find that the support for the MEMBER STATES as central actors in Europe is larger within the left and right of the political spectrum than it is in the centre. By contrast, there appears to be much less support in the ideological extremes for the role of the Commission. Regarding the EP, only the right has a more negative view of a possible strengthening of its powers.

\section{Scope of Governance}

Analysing the topic of the future institutional development of the EU in terms of policy areas, and more specifically the question of support for a unified tax system for the EU, the majority of both politicians and businesspeople agree that this should be implemented in the next ten years (Table 7). When we deconstruct the elements of the political elite, we find the strongest support among the respondents of the PS, while the more right-wing elements are against it.

Concerning a common social security system in Europe, the political and the economic elites are overwhelmingly supportive of this scheme, but those who are 'strongly' in favour are in a larger proportion among businesspeople (32 per cent) than MPs (22 per cent). Ideological and party lines are irrelevant in this matter, with the exception of the right. These results are surprising. If there is a policy area that typically separates the left from the right, it is social security, and Portugal is no

Table 6 Powers of EU institutions (per cent of respondents)

\begin{tabular}{|c|c|c|c|c|c|c|c|}
\hline & & \multirow[b]{2}{*}{$\begin{array}{l}\text { Political } \\
\text { elite }\end{array}$} & \multirow[b]{2}{*}{$\begin{array}{l}\text { Economic } \\
\text { elite }\end{array}$} & \multicolumn{4}{|c|}{ Political elite } \\
\hline & & & & Left & $\begin{array}{l}\text { Centre- } \\
\text { left }\end{array}$ & $\begin{array}{l}\text { Centre- } \\
\text { right }\end{array}$ & Right \\
\hline The member states ought & Agree strongly & 46 & 38 & 62 & 43 & 38 & 100 \\
\hline $\begin{array}{l}\text { to remain the central actors } \\
\text { of the EU }\end{array}$ & Agree somewhat & 30 & 38 & 25 & 31 & 35 & 0 \\
\hline The European Commission & Agree strongly & 9 & 10 & 0 & 14 & 4 & 0 \\
\hline $\begin{array}{l}\text { ought to become the true } \\
\text { government of the EU }\end{array}$ & Agree somewhat & 34 & 48 & 0 & 33 & 46 & 25 \\
\hline The powers of the European & Agree strongly & 41 & 28 & 62 & 44 & 35 & 0 \\
\hline $\begin{array}{l}\text { Parliament ought to be } \\
\text { strengthened }\end{array}$ & Agree somewhat & 35 & 36 & 12 & 37 & 38 & 50 \\
\hline
\end{tabular}

Source: IntUne 2007 Elite Survey in Portugal. 


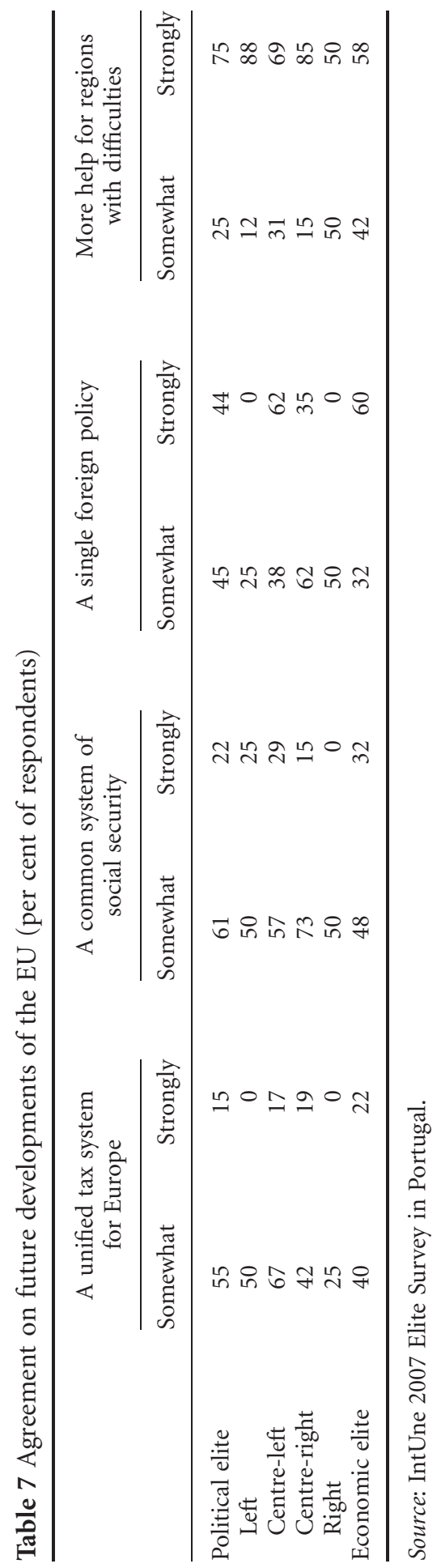


exception. Although the IntUne survey does not possess elements that enable us to capture the motivations of such disparate ideological groups on this topic, we can hypothesise that both the left and the right tend to support a common European security system for different reasons. To the left wing of the Portuguese parliament, the transference of an egalitarian welfare system to the European arena may be seen as the only way to prevent the erosion of the domestic welfare state. On the contrary, the MPs to the right may believe that the perceived neo-liberal tendencies of the European integration process may be another nail in the coffin of the public welfare state.

The responses to the question about a single foreign policy for Europe show a contrast between the politicians and the businesspeople. While the latter are much more enthusiastic in their support (60 per cent 'strongly in favour'), the MPs are much more divided in their positive opinion ( 44 per cent are 'strongly in favour', while 45 per cent are 'somewhat in favour'). It should be noted that the left tends to be strongly opposed to a single European foreign policy, and that on this topic the centre-right is much less enthusiastic than the centre-left (although still somewhat supportive).

The political and economic elites are both in favour of the idea of more help for regions, although MPs are much more supportive ( 75 per cent are 'strongly in favour') than businesspeople (58 per cent are 'strongly in favour'). Among politicians, although all groups are unanimously supportive, the right appears to be less warm in its support.

Finally, we will try to determine the preferred level of governance (regional, national or European) for a series of policy issues according to the perceptions of the Portuguese elites (Tables 8-9). For all these, the regional level is overwhelmingly considered inappropriate, an attitude that probably stems from the non-existence of regional governments in the Portuguese territory (with the exception of the islands of Madeira and the Azores). In fact, Portugal 'has a long tradition of political and administrative centralisation' (Almeida \& Pinto 2003, p. 17), and is today characterised as a 'highly

Table 8 Preferred levels of governance, by policy sector (per cent of respondents)

\begin{tabular}{llccr}
\hline & & $\begin{array}{c}\text { National/ } \\
\text { regional level }\end{array}$ & $\begin{array}{c}\text { European } \\
\text { level }\end{array}$ & $\begin{array}{c}\text { Mixed levels } \\
\text { including European }\end{array}$ \\
\hline Fighting unemployment & Political elite & 42 & 38 & 20 \\
Immigration policy & Economic elite & 58 & 35 & 8 \\
& Political elite & 12 & 68 & 20 \\
Environment policy & Economic elite & 15 & 75 & 10 \\
Fight against crime & Political elite & 6 & 71 & 22 \\
& Economic elite & 18 & 72 & 10 \\
Health care policy & Political elite & 31 & 39 & 30 \\
Taxation & Economic elite & 35 & 45 & 20 \\
& Political elite & 76 & 10 & 5 \\
& Economic elite & 70 & 25 & 20 \\
& Political elite & 41 & 39 & 8 \\
\hline
\end{tabular}

Source: IntUne 2007 Elite Survey in Portugal. 
Table 9 Preferred levels of governance, by policy sector and ideological groups (per cent of respondents)

\begin{tabular}{llccc}
\hline & & $\begin{array}{c}\text { National/ } \\
\text { regional level }\end{array}$ & $\begin{array}{c}\text { European } \\
\text { level }\end{array}$ & $\begin{array}{c}\text { Mixed levels } \\
\text { including European }\end{array}$ \\
\hline Fighting unemployment & Left & 62 & 25 & 12 \\
& Centre-left & 33 & 38 & 29 \\
& Centre-right & 46 & 42 & 12 \\
Immigration policy & Right & 75 & 25 & 0 \\
& Left & 62 & 25 & 12 \\
& Centre-left & 5 & 71 & 24 \\
Environment policy & Centre-right & 12 & 73 & 15 \\
& Right & 0 & 75 & 25 \\
& Left & 12 & 50 & 38 \\
Fighting crime & Centre-left & 5 & 64 & 31 \\
& Centre-right & 8 & 85 & 0 \\
& Right & 0 & 100 & 25 \\
& Left & 62 & 12 & 33 \\
Health care policy & Centre-left & 21 & 45 & 23 \\
& Centre-right & 35 & 42 & 50 \\
& Right & 50 & 0 & 12 \\
Taxation & Left & 75 & 12 & 12 \\
& Centre-left & 79 & 10 & 50 \\
& Centre-right & 77 & 12 & 12 \\
& Right & 50 & 0 & 24 \\
& Left & 50 & 38 & 19 \\
& Centre-left & 31 & 45 & 0 \\
\hline & Centre-right & 50 & 31 & \\
& Right & 75 & 25 & \\
\hline
\end{tabular}

Source: IntUne 2007 Elite Survey in Portugal.

unitarian democracy' (Diamandouros \& Gunther 2001, p. 20). Thus, we will aggregate the regional level with the national one. A second aggregate category includes all answers in which a combination of levels, inclusive of the European level, was suggested by respondents as the most appropriate way to deal with a given policy issue.

Starting with the political elite as a whole, there seems to be a divided opinion over which is the best level of government to handle unemployment: 42 per cent of respondents consider the national/regional level the best to deal with this issue, and 38 per cent prefer the European level. The economic elite is less divided, a majority (58 per cent) preferring the national/regional level. When we look at specific groups, it is once again between the more radicals (left and right) and the moderates (centreleft and centre-right) that the greatest differences emerge: 62 per cent of the left respondents and 75 per cent of the right consider the national level as the most adequate to fight unemployment, while only 33 per cent of the centre-left and 46 per cent of the centre-right feel that unemployment must be resolved at the domestic level.

Immigration policy is largely seen as a European issue. The discordant position is taken by the left, which is the only political group to advocate by a majority 
(62 per cent) that immigration policy should be predominantly dealt with at the national level.

The fight against crime is an issue that divides MPs and businesspeople, although the majority of both groups consider the European level of governance the best to handle this issue. Among politicians, there is an extensive gap between the radicals on one hand and the moderates on the other. To 62 per cent of the left, the national level is the best one; by contrast, 45 per cent of respondents in the centre-left and 42 per cent in the centre-right believe that the European level is the most appropriate.

Environment policy is a consensual issue, since both the political and the economic elites overwhelmingly agree that the European level is the most adequate. A reversed consensus occurs with health care: all groups defend the national level as the most adequate, which seems to be somewhat incongruent with the broad support for a European system of social security. Taxation is a more divisive issue, half of the respondents of both the political and the economic elites preferring the national level of governance, and the other half the European level.

It has been shown (Lengyel et al. 2008) that elite respondents perceive two different groups of issues as related to two different levels of policymaking. Unemployment, healthcare and taxation are deemed by European elites to be mainly domestic/national issues. In turn, environment, immigration and crime are seen as transnational/supranational issues. At the European level, these dimensions were confirmed by factor analysis. However, if we consider exclusively the Portuguese elite sample, factor analysis does not enable us to infer this dichotomy. This means that for the Portuguese case each topic must be analysed individually.

\section{Conclusion}

European citizenship has been defined as a 'compound citizenship' (Cotta 2008), comprising an indirect citizenship, as a consequence of the already existing national citizenship, and a direct citizenship, which is the consequence of European institutions and policies. And, as in the analysis of national citizenship, we can find two distinct linkages between citizens and the polity: a horizontal dimension, that relates to membership in the European polity, and a vertical dimension, that connects the citizens with the political institutions (Cotta \& Isernia 2009).

There are some elements that characterise the horizontal dimension of European citizenship within the Portuguese political elite. As has been argued (Cotta 2008), it is expected that an indirect model of citizenship will result in a weaker level of attachment to the EU than to the national polity. The Portuguese respondents confirm this expectation-45 per cent of the MPs are 'very attached' to the EU, while 92 per cent are strongly attached to their country (see Table 1). This may imply an instrumental allegiance to Europe, since the Portuguese elites overwhelmingly believe that the country has benefited from European integration.

The elements of national and European identity, as they are perceived by the Portuguese elites, show, however, considerable divergence from the generic European 
perception. As argued by Sanders (2008), there exists a mix of ascribed and achieved components in both the European and national identities. In the Portuguese case, beyond the above-mentioned components, European identity is seen as possessing an additional cultural/religious component: those who consider European culture an element of European identity do so because of the religious connotation they attribute to that very European culture.

Despite the secularisation of Europe being an 'undeniable social fact', the decline of regular participation in traditional religious ceremonies seems to be counterbalanced by a relatively high level of private religious beliefs (Casanova 2006, p. 65). This leads some authors to claim that in Europe, at the individual level, secular and Christian cultural identities are not easily separated, or even acknowledged as contradictory concepts (Hervieu-Léger 2000; Casanova 2006). In Portugal, at the elite level, the conception of Christianity is a driving element of European culture. This combines with the secular element of Portuguese national identity, giving further evidence to the paradox that 'secular Europe's boundaries are becoming more sharply defined in religious terms' (Beckford 1994, p. 167, as quoted in Byrnes 2006, p. 284).

As for the vertical dimension of European citizenship (the relationship between the members of the polity and its political authorities), it has been argued that there are elements of a direct linkage (via the EP) and of an indirect linkage (via the European Council of Ministers), while the Commission is at the crossroads (Cotta 2008). Like their European counterparts, the majority of Portuguese respondents defend the strengthening of the powers of Parliament as well as the role of member states as central actors in the process of Europeanisation. In most EU countries, support for the Commission is, however, much weaker among MPs than among businesspeople. This has been interpreted as a resistance of the national political elites to abdicating their role in the guidance of the European process. Actually, the EP is much more connected to the national polity (via elections that have a markedly national character) than the Commission (Cotta 2008).

This weaker support for the Commission on the part of the MPs also corresponds to a lower level of trust. They trust the Council of Ministers and the EP more than they trust the Commission. Economic elites have the opposite view: they trust the Commission more than the other EU institutions. Yet, both elite groups trust Portuguese political institutions more than their European counterparts. This contradicts a dominant trend in public opinion surveys (European Commission 2008a, p. 36). Traditionally, the Portuguese trust the European institutions in general more than they do national institutions. The fact that elite attitudes are so different from the rest of the population on this topic is intriguing, and may be justified by the greater influence of both economic and political elites in their national institutions. However, when asked if national interests are taken into consideration in Brussels, the majority of the political elite believes that they are, while the bulk of the businesspeople believe they are not. Here, the opinion of the latter converges with that of ordinary Portuguese citizens (European Commission 2008b, p. 28). These differences of opinion could indicate that 
businesspeople do not feel that they have much influence in Brussels, unlike the MPs, who would tend to present their own actions in the best light possible.

Regarding the scope of governance, it has been argued that the results of the survey in most member states show the existence of two types of topics correlated with different preferred policymaking levels (Lengyel et al. 2008). Unemployment, healthcare and taxation are deemed by European elites to be mainly domestic/national issues. In turn, environment, immigration and crime are seen as transnational/ supranational issues. Although it is not negligible, this dichotomy does not appear to be so relevant in the Portuguese case.

To conclude, despite some differences between the Portuguese and the European results regarding the IntUne elite survey, we find that the concept of a 'compound citizenship' (Cotta 2008) may be applied to perceptions of the Portuguese elites regarding the EU. Although further study is necessary to refine some of its dimensions, the combination of an indirect European citizenship with a direct one appears to exist in Portugal. And, as has been argued for the EU countries as a whole, this European 'compound citizenship' is not in conflict with national citizenship. On the contrary, it possesses elements for strengthening their linkage.

\section{Acknowledgements}

This research was funded by a grant from the IntUne project (Integrated and United: A Quest for Citizenship in an Ever Closer Europe) financed by the Sixth Framework Programme of the EU, Priority 7, Citizens and Governance in a Knowledge Based Society (CIT3-CT-2005-513421). The authors acknowledge the assistance of Manuela Galhardo in revising the English version, and the criticisms of two anonymous referees.

\section{Notes}

[1] As regards the deputies, the group of frontbenchers interviewed comprises all six leaders of the party parliamentary groups, most chairs (ten out of 12) of the standing committees and 25 former government members. The businesspeople - top leaders of the largest enterprises and bankswere selected from a list of the 'Top 500' corporations, ranked according to revenue, published by the magazine Exame in 2006. Most of the interviews (106 out of 120) were face to face.

[2] A small organisation founded in 1982 and orbiting around the Communist Party.

[3] In the legislative election of 2005 the combined vote for the two major parties slightly declined (from 78 to 73.8 per cent), a reversal that was clearly confirmed in 2009 (65.7 per cent). In 2009, the sum of the parliamentary seats gained by PS and PSD also declined sharply, reaching its lowest level (77.4 per cent) since 1987.

\section{References}

Alípio, E. (2006) Salazar e a Europa. História da adesão à EFTA, 1956-1960, Livros Horizonte, Lisbon.

Almeida, P. Tavares de \& Pinto, A. Costa (2003) 'Portuguese ministers, 1851-1999: social background and paths to power', in Who Governs Southern Europe, eds P. Tavares de Almeida, A. Costa-Pinto \& N. Bermeo, Routledge, London, pp. 5-40. 
Almeida, P. Tavares de \& Freire, A. (2005) 'Two overwhelming victories of the Portuguese left: the 2004 European election and the 2005 legislative election', South European Society \& Politics, vol. 10 , no. 3 , pp. $451-464$.

Álvarez-Miranda, B. (1996) Sur de Europa y la adhesión a la Comunidad: los debates politicos, CIS and Siglo XXI de España, Madrid.

Bacalhau, M. (1994) Atitudes, opiniões e comportamentos políticos dos portugueses, 1973-1993, Fundação Luso Americana para o Desenvolvimento, Lisbon.

Barreto, A. (2003) 'Social change in Portugal: 1960-2000', in Contemporary Portugal. Politics, Society and Culture, ed. A. Costa-Pinto, SSM/Columbia University Press, New York, pp. $159-182$.

Barroso, J. M. (1983) Le système politique portugais face à l'integration européenne: partis politiques et opinion publique, Associação Portuguesa para o Estudo das Relações Internacionais, Lisbon.

Beckford, J. (1994) 'Final reflections', in Religion in Contemporary Europe, eds J. Fulton \& P. Gee, Edwin Mellen Press, Lewiston, pp. 160-168.

Bermeo, N. (1988) 'Regime change and its impact on foreign policy: the Portuguese case', Journal of Modern Greek Studies, vol. 6, no. 1, pp. 12-26.

Byrnes, T. A. (2006) 'Transnational religion and Europeanization', in Religion in an Expanding Europe, eds T. A. Byrnes \& P. J. Katzenstein, Cambridge University Press, Cambridge, UK, pp. $283-305$.

Casanova, J. (2006) 'Religion, European secular identities, and European integration', in Religion in an Expanding Europe, eds T. A. Byrnes \& P. J. Katzenstein, Cambridge University Press, Cambridge, UK, pp. 65-92.

Cotta, M. (2008) 'A "compound" model of citizenship? European citizenship in the eyes of national elites', paper presented at the Lisbon IntUne General Assembly, 27-30 November.

Cotta, M. \& Isernia, P. (2009) 'Citizenship in the European polity: questions and explorations', in Institutional Challenges in Post-Constitutional Europe. Governing Change, eds C. Moury \& L. de Sousa, Routledge, London, pp. 71-94.

Cruz, M. Braga da (1993) 'National identity in transition', in The New Portugal: Democracy and Europe, ed. R. Herr, Institute of International and Asia Studies, Berkeley, pp. 151-162.

Diamandouros, P. N. \& Gunther, R. (eds) (2001) Parties, Politics and Democracy in the New Southern Europe, Johns Hopkins University Press, Baltimore.

European Commission (2008a) Eurobarometer no. 69. National Report on Portugal, available at http:// ec.europa.eu/public_opinion/archives/eb/eb69/eb69_pt_nat.pdf.

European Commission (2008b) Eurobarometer no. 70. National Report on Portugal, available at http://ec.europa.eu/public_opinion/archives/eb/eb70/eb70_pt_exec.pdf.

Hervieu-Léger, D. (2000) Religion as a Change of Memory, Transaction Books, New Brunswick.

Leitão, N. A. (2007) Estado Novo, democracia e Europa, Imprensa de Ciências Sociais, Lisbon.

Lengyel, G., Real-Dato, J. \& Göncz, B. (2008) 'Intra- and inter-elite consensus and dissensus on European policy making and policy priorities', paper presented at the Lisbon IntUne General Assembly, 27-30 November.

Linton, R. (1936) The Study of Man, D. Appleton-Century, New York.

Lucena, M. de \& Gaspar, C. (1991) 'Metamorfoses corporativas? Associações de interesses económicos e institucionalização da democracia em Portugal (I)', Análise Social, vol. 26, no. 114, pp. 847-903.

Parsons, T. (1951) The Social System, Free Press, Glencoe.

Pinto, A. Costa \& Teixeira, N. (2003) 'From Africa to Europe: Portugal and European integration', in Southern Europe and the Making of the European Union, eds A. Costa Pinto \& N. Teixeira, SSM/Columbia University Press, New York, pp. 3-40. 
Pinto, A. Costa \& Lobo, M. Costa (2004) 'Forging a positive but instrumental view: Portuguese attitudes towards the EU, 1986-2002', in Public Opinion and Europe. National Identities and the European Integration Process, eds A. Dulphy \& C. Manigand, Peter Lang, Brussels, pp. $165-181$.

Sanders, D. (2008) 'European identity: evidence from the IntUne surveys of elite and mass publics in 16 European countries', paper presented at the Lisbon IntUne General Assembly, 27-30 November.

Diogo Moreira is a $\mathrm{PhD}$ candidate in-Comparative Politics at the Institute of Social Sciences, University of Lisbon. His research interests include the study of political elites, democratic transitions and electoral systems. He has recently co-authored Para a Melhoria da Representação Política: A Reforma do Sistema Eleitoral (Sextante 2009, with A. Freire and M. Meirinho).

João Pedro Ruivo is a $\mathrm{PhD}$ candidate in Comparative Politics at the Department of Political Studies, Faculty of Social Sciences and Humanities, Universidade Nova de Lisboa. He was the fieldwork coordinator of the first wave of the IntUne elite survey in Portugal.

António Costa Pinto is Professor of Politics and Contemporary European History at the Institute of Social Sciences, University of Lisbon. His research interests include authoritarianism, democratisation, political elites and the EU. His has recently edited Ruling Elites and Decision Making in Fascist-era Dictatorships (Columbia University Press 2009).

Pedro Tavares de Almeida is Professor of Political Science at the Department of Political Studies, Faculty of Social Sciences and Humanities, Universidade Nova de Lisboa. He has written extensively on state-building, elections and elite recruitment in contemporary Portugal. He edited Who Governs Southern Europe? Regime Change and Ministerial Recruitment, 1850-2000 (Frank Cass 2003, with A. Costa Pinto and N. Bermeo). 